第2日

\section{第4 会場}

（富山国際会議場2F 多目的会議室201+202）

9:45 10:35

\section{情報処理}

座長

沖健康クリニック

\section{2-1}

\section{法人施設内の効率的運用を目指した読影体制}

\author{
カーム尼崎健診プラザ 情報科 1$)$ \\ 愛仁会総合健康センター ${ }^{2}$ \\ $\begin{array}{cccc}\text { ○村上 } & \text { 典秀 }^{1)} & \text { 田中 } & \text { 芳生 } \\ \text { 村上 } & \text { 淳 } & \text { 橋本 } & \text { 昭利 }{ }^{1)}\end{array}$
}

\section{【目的】}

当法人グループは平成 20 年 4 月より大阪府高槻市に健康 診断専門施設（以下、既存施設）を設立・運営開始した。 それに加え、新たに平成 26 年 4 月より兵庫県尼崎市にも 健康診断専門施設（以下、新規施設）を設立・運営開始 した。今回放射線読影を既存施設にて一元化し、共有シ ステム掠よび共有サーバーを用いて両施設が健診当日の 診察時に医師より画像診断結果を説明できるよう効率的 遠隔読影システムを構築したので報告する。

\section{【対象】}

平成26年 4 月 1 日から 8 月 31 日までに既存施設と新規施 設を受診した人間ドック 1,900 人・一般健診 10,972 人の画 像情報（胸部 X 線・胃部 X 線・CT・MRI・マンモグラ フィー）とした。

\section{【方法】}

既存施設と新規施設をネットワーク（ケイ・オプティ コム：IP-VANベストエフォート最大100M）でつな き、各施設の画像撮影機器で撮影した情報を PACS サー バーに自動送信することにより、両施設共有システムに 反映され、放射線読影医師が所見付を開始し結果入力し た。

\section{【結果】}

対象とした受診者の当日結果説明は、受診者が診察に到 着するまでに読影医師による所見付が $100 \%$ 終了し、診 察医も診察時には所見を確認でき受診者に結果説明が行 われ効率化が図れた。また日々実施しているアンケート にも診察時に待たされたなどの意見もなく、当日レント ゲン結果が聞けてよかったなど好意的な意見が多かっ た。

\section{【考察】}

遠隔読影システムの構築により読影医師の効率化を図る ことができた。今後受診者が増えてきた場合でも当日結 果説明まで実施できるような、健診順路の検討及びネッ トワーク回線の容量碓保などが課題と考える。 


\section{2-2}

\section{地域連携システム及び遠隔読影システムにつ いて}

一般社団法人 半田市医師会健康管理センター

$\begin{array}{rrrrrr}\text { ○近藤 } & \text { 容圭 } & \text { 倉部 } & \text { 輝久 } & \text { 河野 } & \text { 太郎 } \\ \text { 谷川 } & \text { 剛直 } & \text { 新美 } & \text { 直樹 } & \text { 都築 } & \text { 雄士 } \\ \text { 荻村 } & \text { 卓 } & \text { 花井 } & \text { 俊博 } & & \end{array}$

\section{【目的】}

レポーティングシステムによる画像の所内・所外遠隔読 影や比較読影についての運用上の問題点や不具合の検 証。

\section{【方法】}

画像管理サーバーとしてクラウド機能を有する日立製画 像サーバー、マッチングサーバーと、この PACS との 連携によるオンライン地域連携システムとして Dr.Web 運用上での問題点や改善点を読影医や開業医、連帯医療 機関等を含め検討する。

\section{【結果】}

レポーティングシステムとマッチングサーバーの導入に より読影提出から結果返却までの期間短縮、読影結果を 健診システムに自動転送することにより結果入力の省略 による人件費などのコスト削減及び遠隔で過去画像と比 較読影できるため読影精度の向上ができた。また、キー 画像入りの読影結果の一覧表・個人票を作成できるよう になり健診システムのプリントサーバーと連動させて人 の手を介さずに読影結果票を PDF で出力し個人結果票 に差し込みできるようになった。オンライン地域連携シ ステム Dr.Web 上で登録医院にオンラインでの画像貸出 ができるようになった。その他、予期するトラブル等は 特になかった。

\section{【考察】}

今後の目標として各個人の健診結果全デー夕の時系列表 示、それによる臨床応用を目指す。最終的には、地域内 の医療機関で各個人データを共有、フィードバックし、 次世代の地域医療ネットワークを構築する。

\section{2-3}

PACS・レポートサーバーと健診システムと の連携

一般社団法人 岡崎市医師会

$\begin{array}{rrrrrr}\text { ○鶴田 } & \text { 義人 } & \text { 康田 } & \text { 雅人 } & \text { 鏡味 } & \text { 幹弘 } \\ \text { 志賀 } & \text { 晃路 } & \text { 野澤 } & \text { 稔 } & \text { 岩波登志貴 } \\ \text { 深津 } & \text { 満 } & \text { 山田 } & \text { 珠樹 } & \text { 大浜 } & \text { 仁也 } \\ \text { 後藤 } & \text { 敏之 } & & & & \end{array}$

\section{【目的】}

当センターでは、PACS・レポートサーバーを導入し、 基幹システムとのオンラインによるシステム連携を構築 した。そのPACS・レポートサーバーと基幹システムと の連携について、検査オーダーから健診システムへ結果 が入力されるまでの流れ及び機能を報告する。

\section{【対象】}

当センター人間ドック及び出張健診における画像診断 検查を対象 (胸部・胃部 X 線、超音波、内視鏡、マン モグラフィーなど)。平成 24 年度施設内受診者 76,283 名。 出張健診58,941名。

\section{【方法】}

読影に必要な検査情報（問診・前回結果など）をレポー 卜画面に表示するためにHL7を拡張し、検查オーダー と共に基幹システムより検查情報の送信を行う。レポー 卜画面は各検查専用の読影面面を構築し、スムーズに結 果が入力できるようになっている。レポート画面での結 果確定後、自動的に健診システムに読影結果が送信され、 結果が入力される。

\section{【結果】}

オンラインで基幹システムとの連携を強化したことによ り、検查から結果入力までの工程がスムーズに処理する ことができるようになった。また、オフライン作業によ る手間や人的ミスも無くなり、作業者の負担の軽減、精 度の向上につながった。

\section{【考察】}

受診者は年々増加しているが、PACS・レポートサーバー の導入やオンライン化により迅速な処理を行うことがで きている。今後は遠隔地に読影端末を設置することで、 読影医不足を解消し、スピーディな結果報告を進めてい く予定である。 


\section{2-4}

性年齢を考慮したBMIの四分位数の計算法 (スマートフォンで肥満のグループ分け)

赤心堂総合健診センター

○人保田進真宮 裕五島 雅和

\section{【目的】}

赤心堂総合健診センターの 25 年間 30 万人のデータから性 年齢別にBMI の四分位数で肥満を 4 群に分類する方法 を考察した。

\section{【対象】}

平成元年から 25 年までに赤心堂総合健診センターの外来 ドックを来所した 30 万 8 千 117 人を対象とした。

\section{【方法】}

性別、年代別に、BMI の四分位数を求め、横軸に年齢、 縦軸に四分位数をプロットし、二次曲線の近似式を求め た。

\section{【結果】}

$\mathrm{BMI}$ を $\mathrm{Y}$ 変量、年齢を $\mathrm{X}$ 変量とすると、BMI の四分位 数の近似式は次のようになった。男性 $\mathrm{Q} 1 ： \mathrm{Y}=$ $-0.1342 \mathrm{X}^{*} \mathrm{X}+1.3705 \mathrm{X}+18.187 、 \mathrm{Q} 2: \mathrm{Y}=-0.1423 \mathrm{X}^{*} \mathrm{X}$ $+1.4173 \mathrm{X}+19.912 、 \mathrm{Q} 3: \mathrm{Y}=-0.1393 \mathrm{X}^{*} \mathrm{X}+1.3036 \mathrm{X}+$ 22.286。40歳未満の女性 $\mathrm{Q} 1$ は $\mathrm{Y}=0.275 \mathrm{X}^{*} \mathrm{X}-1.065 \mathrm{X}$ $+19.775 、 \mathrm{Q} 2$ は $\mathrm{Y}=0.4 \mathrm{X}^{*} \mathrm{X}-1.64 \mathrm{X}+21.8 、 \mathrm{Q} 3$ は $\mathrm{Y}=$ $0.425 \mathrm{X}^{*} \mathrm{X}-1.695 \mathrm{X}+23.625$ 。40歳以上の女性 $\mathrm{Q} 1: \mathrm{Y}=-$ $0.0929 \mathrm{X}^{*} \mathrm{X}+1.2243 \mathrm{X}+20.20203 、 \mathrm{Q} 2: \mathrm{Y}=-0.15 \mathrm{X}^{*} \mathrm{X}+$ $1.81 \mathrm{X}+16.76 、 \mathrm{Q} 3: \mathrm{Y}=-0.1393 \mathrm{X} * \mathrm{X}+1.3036 \mathrm{X}+22.286$ 。

\section{【考察（ホームページの作成）】}

BMI は四分位数を用いて 1 群 (小)、 2 群 (中)、 3 群 (高)、4 群（大）の 4 群に分けられる。1 群は $\mathrm{Q} 1$ 未満、 2 群は $\mathrm{Q} 1$ 以上かっ $\mathrm{Q} 2$ 未満、3 群は $\mathrm{Q} 2$ 以上かつ $\mathrm{Q} 3$ 未満、 4 群は Q3 以上とした。性別、年齢を入力して BMI を 4 グループのうちどれに属するかを判定するホームページ をHTMLとCGIを用いて作成し、FTPでプロバイダ 一に送信し、スマートフォンなどによる利用を可能にし た。

\section{【まとめ】}

スマートフォンに性別、年齢、BMI を入力すると BMI が 4 グループのどこに属するかを知ることができる。

\section{2-5}

受診者のID管理による健診業務全般の効率化 についての取り組み

\author{
医療法人社団進興会 せんだい総合健診クリニック 1 ) \\ 医療法人社団進興会 ${ }^{2)}$

○川向 由紀 ${ }^{1 ｝} &{\text { 佐東 }} &{\text { 弘幸 }} \\{\text { 1) }} &{\text { 三浦 信彦 } 1)} \end{array}$

\section{【目的】}

当会では、健診の事前準備・当日の受付処理・健診・結 果処理などの多種多様な場面において、常に受診者属性 のチェックを行い、正確な情報を保持しながら業務を 行っている。しかし、情報が散在しており、それらをマッ チングするためには、多大な労力と時間がとられること が多いため、各種改善を試み、業務の迅速化と正確性を 追究することを検討した。また、2010年度にバーコード を利用した通過管理システムを導入したので合わせて報 告する。

\section{【対象】}

2010年 4 月〜 2013年 3 月。

当会に来院した全受診者約 218,000 人。

\section{【方法】}

1. 受診者に付番されているIDをキーにし、施設内リ スト(受診チェックリスト・前回受診履歴チェック表) を補強する。

2. ID をバーコード化し、検査直前の本人確認・属性 情報を取得するなど各業務場面で活用する。

3. バーコードを利用した各検査の通過管理を行う。

\section{【結果】}

1.リスト利用によって、健診を行いながら、受診日時 や検査項目の確認、過去の検査履歴や所見・判定など が参照できるようになった。

2. バーコードの利用により、本人確認が容易になり、 結果説明で過去結果もすぐに表示できるようになっ た。受付時間・会計処理が簡易化し、健診時間の大幅 な短縮につながった。バーコードリーダーをスタンド 式にしたことで、読取時間が短縮した。

3 . 通過管理システムを運用後、検査もれが少なくなった。

\section{【考察】}

今回の改善で、精度の高い検査ができるようになり、健 診の質の向上につながった。また、健診時間の短縮によ り、受診者の受け入れ人数も増やすことが可能となった。 今後は通過管理システムの精度をさらにあげ検査項目の 正確性を向上させていきたい。 